\title{
The Simple Analytics of Monetary Policy: A Post- Crisis Approach
}

\section{Citation}

Friedman, Benjamin M. 2013. The Simple Analytics of Monetary Policy: A Post-Crisis Approach. The Journal of Economic Education 44, no. 4: 311-328.

\section{Published Version}

doi:10.1080/00220485.2013.825109

\section{Permanent link}

http://nrs.harvard.edu/urn-3:HUL.InstRepos:14117757

\section{Terms of Use}

This article was downloaded from Harvard University's DASH repository, and is made available under the terms and conditions applicable to Open Access Policy Articles, as set forth at http:// nrs.harvard.edu/urn-3:HUL.InstRepos:dash.current.terms-of-use\#OAP

\section{Share Your Story}

The Harvard community has made this article openly available.

Please share how this access benefits you. Submit a story.

Accessibility 
NBER WORKING PAPER SERIES

\title{
THE SIMPLE ANALYTICS OF MONETARY POLICY: A POST-CRISIS APPROACH
}

Benjamin M. Friedman

Working Paper 18960

http://www.nber.org/papers/w18960

\author{
NATIONAL BUREAU OF ECONOMIC RESEARCH \\ 1050 Massachusetts Avenue \\ Cambridge, MA 02138 \\ April 2013
}

This paper was prepared for the session on "After the Crisis: What Did We Learn, and What Should We Teach, about Monetary Policy?" sponsored by the AEA Committee on Economic Education, at the AEA meetings in San Diego, January 5, 2013. I am grateful to numerous colleagues, and especially Kenneth Kuttner, for helpful conversations. The views expressed herein are those of the author and do not necessarily reflect the views of the National Bureau of Economic Research.

NBER working papers are circulated for discussion and comment purposes. They have not been peerreviewed or been subject to the review by the NBER Board of Directors that accompanies official NBER publications.

(C) 2013 by Benjamin M. Friedman. All rights reserved. Short sections of text, not to exceed two paragraphs, may be quoted without explicit permission provided that full credit, including $(\mathbb{C}$ notice, is given to the source. 
The Simple Analytics of Monetary Policy: A Post-Crisis Approach

Benjamin M. Friedman

NBER Working Paper No. 18960

April 2013

JEL No. E52

\begin{abstract}
$\underline{\text { ABSTRACT }}$
The standard workhorse models of monetary policy now commonly in use, both for teaching macroeconomics to students and for supporting policymaking within many central banks, are incapable of incorporating the most widely accepted accounts of how the 2007-9 financial crisis occurred and incapable too of analyzing the actions that monetary policymakers took in response to it. They also offer no point of entry for the frontier research that many economists have subsequently undertaken, especially research revolving around frictions in financial intermediation. This paper suggests a simple model that bridges this gap by distinguishing the interest rate that the central bank sets from the interest rate that matters for the spending decisions of households and firms. One version of this model adds to the canonical "new Keynesian" model a fourth equation representing the spread between these two interest rates. An alternate version replaces this reduced-form expression for the spread with explicit supply and demand equations for privately issued credit obligations. The discussion illustrates the use of both versions of the model for analyzing the kind of breakdown in financial intermediation that triggered the 2007-9 crisis, as well as "unconventional" central bank actions like large-scale asset purchases and forward guidance on the policy interest rate.
\end{abstract}

\author{
Benjamin M. Friedman \\ Department of Economics \\ Littauer Center 127 \\ Harvard University \\ Cambridge, MA 02138 \\ and NBER \\ bfriedman@harvard.edu
}


January, 2013

AEA Meetings

\title{
THE SIMPLE ANALYTICS OF MONETARY POLICY: A POST-CRISIS APPROACH
}

\author{
Benjamin M. Friedman \\ William Joseph Maier Professor of Political Economy \\ Harvard University
}

The financial crisis that struck most of the world's advanced industrialized economies during 2007-9 has presented a major challenge for economists concerned with economic fluctuations, and especially for those interested in the workings of monetary policy. By many measures the crisis constituted the most significant macroeconomic event since World War II. Further, the origin of these events (as the label suggests) was squarely in the financial sector, and the policy actions that governments in many countries took in response, first during the crisis and then in the post-crisis recovery effort, importantly involved monetary policy. Yet the models of monetary policy now commonly in use, both for teaching students in the field and for supporting policymaking within central banks, are not only incapable of incorporating the most widely accepted accounts of how this episode occurred but incapable too of analyzing the actions that monetary policymakers took. The gap between the models and the world of monetary policymaking is now wider than at any time since the 1930s.

\footnotetext{
* This paper was prepared for the session on "After the Crisis: What Did We Learn, and What Should We Teach, about Monetary Policy?" sponsored by the AEA Committee on Economic Education, at the AEA meetings in San Diego, January 5, 2013. I am grateful to numerous colleagues, and especially Kenneth Kuttner, for helpful conversations.
} 
The events triggered by the 2007-9 crisis have proved to be one of the most significant economic phenomena observed among the high-income economies in decades. In many countries the costs of the downturn - costs in terms of reduced production, lost jobs, shrunken investment, and foregone incomes and profits - exceeded that of any previous post-World War II decline. In most of these countries, the recovery from this downturn remained far from complete as of yearend 2012. And, much more so than in most economic fluctuations, not only did financial developments trigger the downturn but once events were in progress it was in the financial sector that this episode especially stood out. The collapse of major financial institutions, the decline in asset values and consequent destruction of paper wealth, the interruption of credit flows, the loss of confidence both in firms and in credit market instruments, and the fear of default by counterparties, were all extraordinary. Above all, the aggressive intervention during the crisis by governments, importantly including central banks, charted new ground both in scale and in scope. In most of the worst-affected countries, the focus of the postcrisis recovery effort has been (and at the time of writing remains) largely on monetary policy.

For economists, however - and especially for macroeconomists, and even more so for those whose interest centers on monetary policy - the consequence of these events has been a crisis of a different kind. The analytical models that have become standard in the field over the last generation are not only incapable of explaining what happened during this unusually significant episode, but unsuited even to incorporating most of the now widely accepted accounts of it. Today's standard macro-models, whether found in undergraduate textbooks or in use in graduate-level macroeconomics instruction, typically include no financial-sector variables other than a short-term interest rate and (perhaps) the quantity of "money," and no way for what happens in the financial arena to affect nonfinancial economic activity other than via the interest 
rate's role in inter-temporal consumer choice (and perhaps an influence of real money balances, also on consumption). The larger empirical models used by many central banks have more expanded detail, and make explicit a variety of real and nominal rigidities, but still the basic mechanism is the same. ${ }^{1}$ Neither offer any way to understand why the failure of a firm like Lehman Brothers, in September 2008, would have had a meaningful effect on the economy, or why it mattered that governments in the United States and elsewhere acted vigorously to prevent other firms from failing. Nor do these models offer any explanation of why or how the unusual actions that central banks took - establishing special lending facilities for banks, purchasing targeted securities like commercial paper and residential mortgages, providing forward guidance on the policy interest rate - would have had any effect. According to the models, once the central bank's policy interest rate reached the practical lower bound of zero, monetary policy simply had no further role to play.

The response to these real-world events on the part of economists engaged with frontier research has presented yet a further challenge, to them as well as to students of the discipline. To their credit, macroeconomists and others have reacted to the crisis with a profusion of new research efforts exploring the workings of financial intermediation and asset holding, and investigating in particular the implications of a variety of "frictions" that intermediation inherently entails under conditions that obtain in any even moderately advanced economy. ${ }^{2}$ But there is no point of contact between most of this work and the standard workhorse models. This gap in turn creates two parallel problems: Students seeking to understand how one or another strand of this new research fits into the canonical macroeconomic framework they are learning see an unbridged chasm between two seemingly incompatible lines of thinking about what is clearly the same set of behavioral phenomena. And, in contrast to earlier eras in the 
development of macroeconomics (see Harry Johnson's (1971) insightful essay), researchers seeking to establish the motivation for their work, among more than a narrow audience of fellow specialists, are able to appeal to what everyone has read in the newspapers but not to what the field holds out as the accepted conceptual overview.

One ready example of this divide is the behavior of central bank balance sheets, both during and in the aftermath of the crisis. As Table 1 shows, most of the advanced economies' central banks responded to the crisis by rapidly expanding their balance sheets, purchasing assets in the open market and correspondingly issuing liabilities. The Bank of England increased its balance sheet nearly five-fold, from $£ 85$ billion at the beginning of 2007 to $£ 415$ billion by late 2012. Both the U.S. Federal Reserve System and Sweden's Riksbank expanded their balance sheets more than three-fold (although by yearend 2012 the Riksbank's assets were back to only double what they had been at the beginning of 2007). At the European Central Bank the expansion was nearly three-fold, and at the Bank of Canada nearly two-fold. Among the major central banks, only the Bank of Japan increased its balance sheet during these years by less than fifty percent, but only because - in an example of the exception's proving the rule - the BOJ, facing more than a decade of deflation and economic stagnation before the 2007-9 crisis set in, had already greatly expanded its balance sheet beforehand (but then shrunk it somewhat in the period just before the crisis set in). By yearend 2012 the size of the BOJ's balance sheet was nearly double what it had been in 2000 .

Moreover, this radical departure in central bank asset holding was not just a matter of total quantity; the character of the assets these central banks held changed abruptly as well. Traditionally, most of the assets that central banks hold have been obligations of their own governments, and within those, mostly short-term obligations. As Figure 1 shows for the case of 
the United States, in the initial stages of the crisis - even before its balance sheet began to expand - the Federal Reserve massively (with nearly half of its asset portfolio) substituted loans to specific financial institutions for its customary holdings of U.S. Treasury securities. When it then suddenly began to expand its holdings, immediately after the Lehman failure, it did so not by purchasing the usual Treasuries but by making more of these special loans. It also began to purchase securities issued by private-sector borrowers: first commercial paper and then, in even larger volume, residential mortgages. By mid 2010, mortgage holdings represented nearly half (47 percent) of the Federal Reserve's entire portfolio. As of yearend 2012, with the total balance sheet now at $\$ 3$ trillion, mortgages still constituted 31 percent of total assets.

Why did the U.S. central bank undertake this massive expansion of its asset holdings? And what reason did it have for doing so primarily via loans to banks and then purchases of commercial paper and mortgages? Why should an informed economist have expected these actions to affect either the financial markets or, more importantly, nonfinancial activity? By what metric would one judge whether these actions were effective? Students educated to view the macroeconomy and the role of monetary policy through the standard models have no way even to begin to pursue any of these very natural questions. And the researchers who have pursued them have little way to connect their work to the conceptual frameworks that the standard models offer.

Analogous questions arise from looking at these central banks' liabilities. Central banks' balance sheets, like those of other entities, balance. The huge increase in asset holdings with which they responded to the crisis - see again Table 1 - therefore meant an equally huge increase in their outstanding liabilities. Students taught to view the macroeconomy through the lens of central bank (or "high powered") money supply would presumably have expected not just 
an increase of a few percentage points in these economies' rates of inflation but a massive inflation, perhaps even reminiscent of what occurred in Germany and Russia after World War I or in Hungary after World War II. Indeed, more than a few economists predicted just such a consequence of these extraordinary central bank actions.

But at least as of the time of writing (yearend 2012) no such increase in inflation - not even a few percentage points - has appeared, in any of these economies. (Nor did the increase in inflation that many observers had predicted earlier in Japan, when the Bank of Japan greatly increased its outstanding liabilities starting in the mid 1990s.) To be sure, no one can preclude with certainty even that a hyperinflation, or something like it, may ensue some time somewhere. But even if inflation in these countries does pick up pace at some point, a response of some percentage points to this magnitude of increase in central bank liabilities, and only after a delay of more than half a decade, is widely at variance with the core implications of standard models relating prices to central bank money. Given the huge magnitude of the expansion in central bank balance sheets, and in light of the weight that least-squares statistical methods attach to outlier observations, for the duration of the lifetime of today's students no one will again be able to get economically sensible estimates, for any of the large high-income economies, from what were once standard regressions relating the price level (or its rate of change) to the quantity (or change) of central bank liabilities.

What economists and others interested in the workings of monetary policy now need, therefore, is a conceptual framework within which one can at least begin to ask questions like these - and within which the important research now under way addressing these questions can readily establish a point of entry. The remainder of this paper sketches two versions of a simple model for this purpose. Section 1 lays out a four-equation version, of which two equations are 
identical to familiar elements of the currently standard "new Keynesian" model, one is a variant on what the standard model contains, and one is new. The role of the new equation is to introduce explicitly the relationship between the policy interest rate that the central bank sets and "the" interest rate (a metaphor for a whole constellation of interest rates) that affects the spending decisions of households and firms. Section 2 expands this four-equation representation to five, introducing an explicit supply-demand apparatus in place of the single reduced-form equation for the interest rate spread. The discussion in each section uses examples of actions that many of the advanced economies' central banks took during and in the wake of the crisis but that do not fit within the currently standard canonical models - asset purchases and forward guidance on the policy interest rate - to illustrate the workings of the model. Section 3 briefly concludes.

\section{A Four-Equation Model}

The most familiar workhorse of monetary-policy macroeconomics today is the threeequation "new Keynesian" model consisting of an aggregate demand equation representing consumers' forward-looking inter-temporal choice for a given interest rate, a "Phillips curve" representing the forward-looking behavior of price setters operating under some form of impediment to perfect price flexibility (most typically, as motivated by Calvo (1983)), and an equation representing the central bank's setting of a short-term nominal interest rate in response to observed movements of prices or output or both. ${ }^{3}$ The problem with this model, for current purposes, is not so much that it is wrong but that it is incomplete. Once the central bank's policy interest rate has reached the zero lower bound, the model implicitly portrays monetary policy as impotent to undertake any further economic stimulus. It leaves no room even to consider the kinds of additional measures that many central banks undertook during and in the aftermath of the 2007-9 crisis. 
The remedy, therefore, is not to discard this otherwise useful framework but to expand it - while nonetheless preserving, in so far as possible, its analytical advantages in terms of parsimony and compactness. The model's crucial lacuna, for purposes of representing the actions of central banks during this recent period and their effect on the nonfinancial economy, is the absence of any distinction between the interest rate that the central bank sets - in conventional vocabulary, the "policy interest rate" - and the interest rates at which households and firms regularly borrow and lend, and that therefore matter for their spending decisions, either as direct costs (if they are borrowers/investors) or as opportunity costs (if they are lenders/savers). The simple model suggested here fills that gap: in this section, with a single reduced-form equation directly determining the spread between the policy interest rate and a representative private-sector interest rate; and then, in Section 2, with a two-equation supplydemand apparatus explicitly representing lenders' and borrowers' behavior in the market for private-sector obligations.

Two elements of the standard "new Keynesian" model suffice with no change. Price setters behave according to

$$
\pi_{\mathrm{t}}=\mathrm{E}\left(\pi_{\mathrm{t}+1}\right)+\beta \mathrm{y}_{\mathrm{t}}+\mathrm{u}_{\mathrm{t}}
$$

where $\pi$ is the rate of change of the economy's aggregate price level for goods and services, $y$ is (the log of) aggregate output of goods and services, $u$ is a disturbance term, and the equation may also include an intercept (not shown) so that $\mathrm{y}$ is implicitly measured around some equilibrium level that depends on the economy's resources and technology. And the central bank sets the policy interest rate according to

$$
\mathrm{r}_{\mathrm{t}}=\mathrm{r}^{*}+\gamma_{1}\left(\mathrm{y}_{\mathrm{t}}-\mathrm{y}^{*}\right)+\gamma_{2}\left(\pi_{\mathrm{t}}-\pi^{*}\right)
$$


subject to $r \geq 0$, where $r$ is a short-term nominal interest rate over which the central bank has control, ${ }^{4} \mathrm{y}^{*}$ is the central bank's target level of output (presumably the level that would deliver stable inflation in (1), although for purposes here this need not matter), $\pi^{*}$ is its target rate of inflation, and $r^{*}$ is the equilibrium value of $r$ for given $\pi^{*}$. Equation (1) is the consequence of dynamic optimization by price setters under any of a variety of well known conditions involving imperfect price flexibility (see again the examples in fn. 3), and (2) may be either the outcome of an explicit optimization by the central bank, given a quadratic objective (so that the resulting decision rule is linear), or merely a convenient rule of thumb that policymakers apply.

The third element of the standard model is necessary as well, although with an important change:

$$
y_{t}=\alpha_{1} E\left(y_{t+1}\right)-\alpha_{2}\left(\rho_{t}-E\left(\pi_{t+}\right)\right)+v_{t}
$$

where $\rho$ is the nominal interest rate relevant to private-sector spending decisions, $\mathrm{E}\left(\pi_{\mathrm{t}^{+}}\right)$ indicates the appropriately averaged expectation of inflation over the horizon corresponding to the maturity for which $\rho$ represents the private-sector interest rate, and $\mathrm{v}$ is a disturbance term. Here too the equation may also include an intercept (not shown), so that both y and the expected real interest rate are implicitly measured around their respective equilibrium levels. Although many expositions of the standard model label the equation analogous to (3) an "IS curve" (see, for example, Clarida et al. (1999)), in its most common form the model includes neither firms nor investment and so the equation is not properly a Keynesian IS curve but simply the Euler equation for consumption that follows from households' inter-temporal utility maximization. (The equation also often includes a term for government absorption of output, but the focus here is on monetary policy, not fiscal policy.) The broader interpretation as a genuine IS curve fits as well, however, in that most familiar accounts of firms' investment spending likewise imply a 
negative elasticity with respect to the expected real interest rate, or cost of capital (although it is less obvious that a suitable representation of investment behavior grounded in microeconomic optimization would fit this simple functional form). But regardless of whether (3) represents the behavior of households' consumption or firms' investment or both, the important point is that the nominal interest rate that matters for these decisions is not the policy interest rate that the central bank sets but instead some private-sector rate $-\rho$ - that they would pay on borrowing to finance spending in excess of current income, or that they would earn on unspent income or other accumulated assets.

Distinguishing between these two interest rates means abandoning the assumption, which has been commonplace in standard macroeconomic theory ever since the inception of the field, that all non-money assets are perfect substitutes. ${ }^{5}$ Most central banks normally conduct monetary policy by setting an overnight interest rate, or if not overnight then for some other very short maturity: in the United States the federal funds rate (usually overnight transactions), in Europe the "EONIA" Euro overnight interest average, and in Japan the uncollateralized call loan rate (also mostly one-day loans). By contrast, the obligations that either households or firms issue to finance their spending, and likewise the instruments in which households invest their savings, are typically of much longer maturity, often measured in years rather than days. Further, while the interest rates that central banks set for purposes of monetary policy are mostly for obligations that are implicitly guaranteed - often claims on banks' holdings of reserves at the central bank itself - private-sector obligations are potentially subject to default. On grounds of both maturity and default risk, therefore, the obligations respectively underlying the policy interest rate $r$ and the constellation of private-sector rates that $\rho$ represents are not perfect 
substitutes when investors are risk averse. Moreover, the difference, or spread, between the two interest rates can vary over time even if investors' risk aversion is constant.

With the central bank setting $r$ as in (2), but households and firms making spending decisions based on $\rho$ as in (3), it therefore remains to remains to determine $\rho$ for given $r$. A simple reduced-form relation between the two interest rates that takes into account both the default risk on private obligations and also their longer maturity is

$$
\rho_{\mathrm{t}}=(1-\delta) \mathrm{r}_{\mathrm{t}}+\delta \mathrm{r}_{\mathrm{t}^{+}}^{\mathrm{e}}+\varphi(\mathrm{R} / \mathrm{A})_{\mathrm{t}}+\mathrm{z}_{\mathrm{t}}
$$

where $r_{{ }^{+}}^{e}$ is the policy interest rate that market participants expect to prevail on average in the future over the time horizon corresponding to the private security's maturity, $\delta(0 \leq \delta<1)$ is a parameter that reflects the maturity of the private security $(\delta=0$ when it is identical to the maturity corresponding to the policy interest rate), $\mathrm{R} / \mathrm{A}$ is the ratio of risky to total assets that private-sector investors must hold for the asset market to clear, and $\mathrm{z}$ is a disturbance term. The first pair of terms on the right-hand side reflect the pricing of long- relative to short-term assets according to the familiar expectations theory of the term structure of interest rates; writing the expected future level of the policy interest rate as $\mathrm{r}_{\mathrm{t}^{+}}^{\mathrm{e}}$ instead of $\mathrm{E}\left(\mathrm{r}_{\mathrm{t}^{+}}\right)$makes explicit that under circumstances like forward guidance provided by the central bank, investors' expectations of future central bank actions need not be "rational" in the conventional sense of consistency with the mathematical expectation delivered by the model itself. ${ }^{6}$ The third term reflects the dependence of the market price of risk on the relative supply of risky versus risk-free assets that the market must hold; for given variance associated with the risky asset's expected return, and given risk aversion of investors, the greater is the supply of risky assets in the total market portfolio the larger will be the market-clearing excess return on risky over risk-free assets. ${ }^{7}$ 
Equation (4) introduces the opportunity for the model to incorporate not only influences of the kind that many observers have identified as proximate causes of the $2007-9$ crisis but also key actions that many central banks undertook in response to it. The disturbance $\mathrm{z}$ represents influences on the private-sector interest rate $\rho$ arising from forces outside either the model itself or the actions of central banks. Familiar examples important to the events of 2007-9 are the loss of value of borrowers' collateral when house prices fell, and the reduction in capital of lending institutions due to loan losses. ${ }^{8}$ The term in $\mathrm{r}^{\mathrm{e}}{ }_{\mathrm{t}}$ introduces the opportunity to represent the effect of the central bank's forward guidance on the future level of the policy interest rate. (Doing so in this way also highlights the importance of the market credibility of that guidance: it has an effect only if investors believe it.) The term in R/A introduces the opportunity to represent the central bank's asset purchases; in buying private-sector obligations like commercial paper and mortgages, either in exchange for government obligations or by issuing its own liabilities (normally reserves), the central bank changes the risky/risk-free mix of the market portfolio that private investors in the aggregate must hold.

Figures 2 and 3 illustrate the workings of these new model capabilities that distinguishing the policy interest rate from the relevant private-sector interest rate, and relating the two via an expression like (4), make possible. The downward sloping line labeled "IS" in Figure 2 plots output $y$ as a function of the relevant (that is, the private-sector) interest rate $\rho$, combining equations (1) and (3) for given expectations of future output and inflation. The horizontal line labeled " $r$ " shows the level of the policy interest rate set by the central bank. The horizontal line labeled " $\rho$ " shows the value of the private-sector interest rate, given this value of $\mathrm{r}$ and also for given values of $\mathrm{r}_{\mathrm{t}^{+}}$and $\mathrm{R} / \mathrm{A}$ and an assumed zero realization of disturbance $\mathrm{z}$. The figure makes 
clear that $y$ is determined at the intersection of "IS" with $\rho$, not with $r$. The figure arbitrarily portrays this intersection, marked as point $\mathrm{A}$, at the full-employment output value $\mathrm{y}^{*}$.

Figure 3, in which the horizontal " $r$ " line does not appear, illustrates the impact of an adverse shock to the pricing of private-sector credits - stemming from, say, a decline in house prices, or realized loan losses that deplete lenders' capital, or even simply investors' concern that the economy may be heading into a slow period in which private-sector borrowers' creditworthiness will be under stress. From (4), the positive realization of $\mathrm{z}$ raises $\rho$ with all else equal; the movement from the solid to the broken horizontal line shows the resulting increase to a new, higher level of $\rho$ for the same values of $\mathrm{r}, \mathrm{r}_{\mathrm{t}^{+}}^{\mathrm{e}}$ and $\mathrm{R} / \mathrm{A}$ as before, and the intersection shifts from point A to B. If monetary policymakers want to return the economy to the initial equilibrium at $\mathrm{y}^{*}$, therefore, they must change - specifically, they must reduce - one or more of $\mathrm{r}, \mathrm{r}_{{ }^{+}}^{\mathrm{e}}$ and $\mathrm{R} / \mathrm{A}$. (Alternatively, fiscal policymakers may take measures that shift the IS line outward; but the focus here is on monetary policy.) Under conventional circumstances, when movements of the policy interest rate are not limited by the zero lower bound, the central bank presumably would choose to reduce r. Again from (4), in principle it can fully offset the adverse credit market shock by cutting $\mathrm{r}$ by $\mathrm{z} /(1-\delta)$. If it does so, the resulting representation for $\rho$ is once again the solid horizontal line, which is then conditional on initial values $\mathrm{r}_{\mathrm{t}+, 0}^{\mathrm{e}}$ and $(\mathrm{R} / \mathrm{A})_{0}$ as before, but now $\mathrm{r}=\mathrm{r}_{0}-\mathrm{z} /(1-\delta)$ to offset $\mathrm{z}>0$, and the intersection returns to point $\mathrm{A}$.

For purposes of thinking about monetary policy during and in the wake of the 2007-9 crisis, however, the policy interest rate was already at the zero lower bound and so further cuts were not an option that policymakers faced. Many central banks therefore turned to (often very large-scale) purchases of private-sector assets. In terms of equation (4), their doing so reduced $\mathrm{R}$, the supply of potentially defaultable and also longer-term assets that the market needed to 
hold, without changing A, the total supply of risky plus risk-free assets in the market portfolio. These asset purchases therefore reduced the relative supply ratio R/A, and hence narrowed the spread between the (risk-free) policy interest rate $r$ and the (risky) private-sector interest rate $\rho$.

In terms of a richer model that would explicitly represent a multiplicity of different risky assets (that is, assets that are not perfect substitutes either for the risk-free asset or for one another) and in which $\mathrm{R}$ and $\rho$ would therefore expand to a vectors of quantities and interest rates describing these distinct risky assets, specifically targeted purchases of a security like commercial paper or mortgages would reduce the individual asset supply quantity to be held by private-sector investors $\mathrm{R}_{\mathrm{i}}$, and thereby lower the corresponding market-clearing interest rate $\rho_{\mathrm{i}}$. As the two panels of Figure 4 suggest, and as detailed empirical studies have shown, ${ }^{9}$ the Federal Reserve's purchases of commercial paper (at the peak, $\$ 385$ billion) and then mortgages (at the peak, \$1.1 trillion) - see again Figure 1 - had just this effect. Similarly, a program like the Federal Reserve's “Operation Twist," which involved buying longer-term Treasury securities and either selling shorter-term Treasuries outright or simply allowing them to mature without replacing them, would reduce $R_{i}$ and therefore lower $\rho_{i}$ corresponding to the long-term securities while increasing $R_{i}$ and raising $\rho_{i}$ corresponding to the shorter maturities (if the shorter-term rates are not infra-marginally constrained at zero).

Figure 5 illustrates the working of this kind of asset purchase program, in its generic form, within the model. Once again, the broken horizontal line labeled " $\rho$ " represents the level of the private-sector interest rate following an adverse shock to private intermediation $(\mathrm{z}>0)$, with $\mathrm{r}, \mathrm{r}_{\mathrm{t}^{+}}^{\mathrm{e}}$ and $(\mathrm{R} / \mathrm{A})$ all at their respective initial values, $\mathrm{r}_{0}$ (presumably $\left.=0\right), \mathrm{r}_{\mathrm{t}+, 0}^{\mathrm{e}}$ and $(\mathrm{R} / \mathrm{A})_{0}$. By purchasing risky assets, the central bank reduces $\mathrm{R}$, without affecting $\mathrm{A}$, so that $\mathrm{R} / \mathrm{A}$ becomes smaller. Following (4), $\rho$ therefore falls, even for given values $r_{0}$ and $r^{e}{ }_{t+, 0}$, as indicated by the 
dotted horizontal line. If the central bank were to purchase enough of the risky asset in this way - specifically, if it were to buy $\mathrm{z} \cdot \mathrm{A} / \varphi$ of the risky asset - doing so would lower $\rho$ enough to restore output to $y^{*}$. Figure 5 instead illustrates the more realistic case in which the central bank's purchases fall short of this amount, so that y remains below $\mathrm{y}^{*}$, albeit above what $\mathrm{y}$ would have been without the central bank's action; instead of returning all the way to point A, the intersection moves only from B to C.

A second policy tool to which some central banks turned in the crisis, in the absence of the ability to cut the policy interest rate any further, was forward guidance. The Federal Reserve's Open Market Committee reduced its target for the federal funds rate to $0-1 / 4$ percent in December 2008. At the same time, it publicly stated that "the Committee anticipates that weak economic conditions are likely to warrant exceptionally low levels of the federal funds rate for some time." Apart from a change in wording from "some time" to "an extended period," the Committee repeated the same public statement after each meeting that it held through June 2011. In August 2011, it then switched to a more explicit statement that "the Committee currently anticipates that economic conditions ... are likely to warrant exceptionally low levels for the federal funds rate at least through mid-2013." Thereafter, the committee extended the specific horizon for this forward guidance several times, by late 2012 indicating the anticipation of low short-term interest rates "at least through mid-2015."

These statements, even in their later, more precise form, presented a difficulty of interpretation: were they promises? or merely policymakers' expectations? If they were promises, were they credible? (What if, at some point between late 2012 and mid 2015, the economy were to show signs of a vigorous recovery? Would policymakers leave the target federal funds rate at $0-1 / 4$ percent anyway?) And if they were expectations, in what way did 
they constitute an independent policy tool? After all, policymakers' expectations at any time are what they are. In December 2012, therefore, the Open Market Committee shifted to a new form of statement explicitly conditioned on observed and forecast economic outcomes: "the Committee ... currently anticipates that this exceptionally low level for the federal funds rate will be appropriate at least as long as the unemployment rate remains above $61 / 2$ percent, inflation between one and two years ahead is projected to be no more than a half percentage point above the Committee's 2-percent longer-run goal, and longer-term inflation expectations continue to be well anchored."

One way to view such a statement is as a publicly disclosed decision rule partially overriding the interest rate setting rule in equation (2). An alternative interpretation is that, in the context of the same interest rate setting rule as before, policymakers were revealing their expectation that under the stated conditions $\mathrm{y}$ and $\pi$ would be low enough, relative to $\mathrm{y}^{*}$ and $\pi^{*}$, that the value of $r$ given by (2) would remain at or below the zero lower bound. Either way, the relevant implication for the economy - as long as participants in the securities market take the statement to be credible - is as an influence on $r^{e}{ }^{+}$in (4). Figure 6 shows that the effect of such credible forward guidance is analogous to the effect of central bank asset purchases as illustrated in Figure 5. Here again the broken horizontal line labeled " $\rho$ " represents the level of the privatesector interest rate following an adverse shock to private intermediation $(\mathrm{z}>0)$, with $\mathrm{r}, \mathrm{r}_{\mathrm{t}+}^{\mathrm{e}}$ and (R/A) all at their initial values. With $\mathrm{r}_{\mathrm{t}^{+}}^{\mathrm{e}}<\mathrm{r}_{\mathrm{t}^{+}, 0}^{\mathrm{e}}$ due to forward guidance, the spread narrows and $\rho$ therefore falls for given $r_{0}$ and $(\mathrm{R} / \mathrm{A})_{0}$, as indicated by the dotted horizontal line. Figure 6 once again illustrates the presumably realistic case in which the effect of the central bank's forward guidance - which, like its actual setting of $r$, is restricted by the zero lower bound - is 
insufficient to restore $y$ to $\mathrm{y}^{*}$; once again, instead of returning all the way to point $\mathrm{A}$, the intersection moves only from B to C.

\section{A Five-Equation Model}

The key addition in the model laid out in Section 1, compared to today's standard workhorse model, is the interest rate spread relationship (4). In contrast to equations (1) and (3), however, (4) does not directly represent the optimal behavior of any class of agents within the model. It is instead a reduced-form representation of an economic outcome - in the market in which the households and firms whose spending decisions (3) represents issue, and risk-averse investors purchase, private-sector obligations. Although the resulting four-equation model in Section 1 is sufficient to capture influences like declining house prices and lenders' shrunken capital that were at work in the 2007-9 crisis, as well as actions like asset purchases and forward guidance that central banks took in response, explicitly representing the behavior of borrowers and lenders in the market that determines the key interest rate $\rho$ can further clarify how these shocks and policy actions have their effect.

In an expansion of the spread relationship (4) that makes explicit the roles of the agents on the two sides of this market, households and firms borrow according to

$$
\mathrm{c}_{\mathrm{t}}^{\mathrm{S}}=\varphi_{1} \mathrm{E}\left(\mathrm{y}_{\mathrm{t}+}\right)-\varphi_{2}\left(\rho_{\mathrm{t}}-\mathrm{E}\left(\pi_{\mathrm{t}^{+}}\right)\right)+\mathrm{z}_{\mathrm{t}}^{\mathrm{S}}
$$

where $\mathrm{c}^{\mathrm{S}}$ is the supply of private-sector obligations, and $\mathrm{z}^{\mathrm{S}}$ is a disturbance term.

Correspondingly, private-sector investors - who likewise include households and firms within

the economy, ${ }^{10}$ but perhaps also financial intermediaries as well as foreign investors - lend to households and firms according to

$$
\mathrm{c}^{\mathrm{D}}{ }_{\mathrm{t}}=\theta_{1} \mathrm{E}\left(\mathrm{y}_{\mathrm{t}}\right)+\theta_{2}\left[\rho_{\mathrm{t}}-\left((1-\delta) \mathrm{r}_{\mathrm{t}}+\delta \mathrm{r}_{{ }^{+}}^{\mathrm{e}}\right)\right]+\mathrm{z}^{\mathrm{D}}{ }_{\mathrm{t}}
$$


where $\mathrm{c}^{\mathrm{D}}$ is the demand for private sector obligations, and $\mathrm{z}^{\mathrm{D}}$ is a disturbance term. Supply equation $\left(4^{\mathrm{S}}\right)$ is the adjunct of (3) in a setting in which households maximizing inter-temporal utility of consumption and firms deciding on investment spending are not constrained by their current income and accumulated assets but also have the ability to borrow at nominal interest rate $\rho$. The first term reflects the greater willingness to borrow when expected future income is higher, while the second term reflects the negative influence of the relevant real interest rate on optimal borrowing, all else equal. Demand equation $\left(4^{\mathrm{D}}\right)$ represents the optimal behavior of riskaverse investors allocating their portfolios between private-sector obligations bearing interest rate $\rho$ and the asset corresponding to the central bank's policy interest rate, with return $r_{t}$ in the present and $\mathrm{r}_{{ }^{+}}^{\mathrm{e}}$ expected over the remaining maturity of the private obligations. The first term reflects the improved creditworthiness of private-sector borrowers, all else equal, when their expected incomes are higher, while the second term results from the imperfect substitutability of the two assets in risk-averse investors' portfolios. ${ }^{11}$ With households' and firms' supply of private-sector obligations as in $\left(4^{\mathrm{S}}\right)$, and investors' demand for these obligations as in $\left(4^{\mathrm{D}}\right)$, the market clears when

$$
\mathrm{c}_{\mathrm{t}}^{\mathrm{S}}=\mathrm{c}_{\mathrm{t}}^{\mathrm{D}}+\mathrm{c}^{\mathrm{CB}}{ }_{\mathrm{t}}
$$

where $\mathrm{c}^{\mathrm{CB}}$ is the net purchase of private-sector assets by the central bank. ${ }^{12}$

Figures 7 and 8 illustrate the expanded model's portrayal of an adverse shock to financial intermediation, followed by partially offsetting policy action by the central bank. The downward-sloping IS line in the right-hand panel of each figure is again the relationship between spending and the private-sector interest rate, from (3), as before conditional on given expectations of future output and inflation. The downward-sloping line in the left-hand panel of each figure, labeled "cS", depicts households' and firms' supply of private sector securities, from 
$\left(4^{\mathrm{S}}\right)$, as a function of interest rate $\rho$ and for given expectations $\mathrm{E}\left(\mathrm{y}_{\mathrm{t}+}\right)$ and $\mathrm{E}\left(\pi_{\mathrm{t}+}\right)$ and zero realization of disturbance $z^{S}$. The solid upward-sloping line in the left-hand panel, labeled "c $c^{D}+$ $\mathrm{c}^{\mathrm{CB},}$, correspondingly depicts investors' demand for private sector securities, from $\left(4^{\mathrm{D}}\right)$, as a function of $\rho$ for given expectations $E\left(y_{t+}\right)$, given values of $r$ and $r^{e}+$, and zero realization of disturbance $\mathrm{z}^{\mathrm{D}}$, and a given level of purchases by the central bank $\mathrm{c}^{\mathrm{CB}}$. Both Figures 7 and Figure 8 arbitrarily portray the initial supply-demand equilibrium in the asset market in the lefthand panel (at point A) at the private-sector interest rate level that, when transposed to the righthand panel, intersects with the IS line at the full-employment value $\mathrm{y}^{*}$.

In the expanded model, either a decline in the value of borrowers' collateral or a deterioration of lenders' capital corresponds to a negative realization of disturbance $\mathrm{z}^{\mathrm{D}}$ to investors' demand for private-sector securities. ${ }^{13}$ The result is to shift the demand curve backward for given values $\mathrm{r}_{0}, \mathrm{r}_{\mathrm{t}+0}^{\mathrm{e}}$ and $\mathrm{c}_{0}^{\mathrm{CB}}$, to the respective broken lines in the right-hand panel of Figures 7 and 8, resulting in each case in a higher market-clearing private-sector interest rate $\rho$ and therefore $\mathrm{y}<\mathrm{y}^{*}$ (in both panels, at point B).

Figure 7 illustrates the effect in this situation of additional purchases of private-sector obligations by the central bank, so that $\mathrm{c}^{\mathrm{CB}}>\mathrm{c}^{\mathrm{CB}}$. From $\left(4^{\mathrm{MC}}\right)$, the central bank's purchases are a straightforward addition to the total market demand for these securities, and so they shift the demand curve outward to the dotted line in the left-hand panel, thereby lowering the marketclearing interest rate $\rho$ for given $\mathrm{r}_{0}, \mathrm{r}_{\mathrm{t}+, 0}^{\mathrm{e}}$ and $\mathrm{z}^{\mathrm{D}}<0$. The result in the right-hand panel is an increase in y. (Both intersections are marked as point C.) As before, Figure 7 illustrates the presumably realistic case in which the central bank's purchases $\mathrm{c}^{\mathrm{CB}}$ are not sufficient to restore $\mathrm{y}$ to $\mathrm{y}^{*}$. 
Figure 8 analogously illustrates the working of forward guidance on the future policy interest rate. Reducing $\mathrm{r}_{\mathrm{t}+}^{\mathrm{e}}$ shifts the demand curve downward, again lowering the marketclearing interest rate $\rho$ for given $\mathrm{r}_{0}, \mathrm{c}^{\mathrm{CB}}{ }_{0}$ and $\mathrm{z}^{\mathrm{D}}<0$, as indicated by the dotted line in the lefthand panel of the figure, and raising output $\mathrm{y}$ in the right-hand panel (point $\mathrm{C}$ in each panel). With the linear demand curve assumed here, the downward movement due to $\mathrm{r}_{\mathrm{t}^{+}}^{\mathrm{e}}<\mathrm{r}_{\mathrm{t}+, 0}^{\mathrm{e}}$ in

Figure 8 is visually indistinguishable from the outward movement due to $\mathrm{c}^{\mathrm{CB}}>\mathrm{c}^{\mathrm{CB}}$ in Figure 7; but because of the interaction of $\rho$ and $r^{e}{ }_{t+}$ in $\left(4^{D}\right)$, the movement due to changed $r_{t+}^{e}$ is vertical, not horizontal. Here too the figure illustrates the case in which the effect of the central bank's forward guidance is not sufficient to restore $\mathrm{y}$ to $\mathrm{y}^{*}$ - presumably because of the zero lower bound on $r$.

Finally, if the policy interest rate is not already at the zero lower bound, the central bank can achieve the same downward movement of the demand curve shown in Figure 8 by cutting $r$, rather than resorting to forward guidance to reduce $r_{t+}^{e}$. But the chief purpose of the model developed here is to facilitate analysis of the "unconventional" monetary policy actions that central banks took when - and because - reducing the policy interest rate was not an available option.

\section{In Conclusion}

The practice of monetary policy, as carried out by the central banks of the advanced industrialized economies, has changed since the 2007-9 financial crisis. The analysis of monetary policy needs to change as well. Monetary policy is no longer merely a matter of the central bank's setting some short-term nominal interest rate. Once they had cut their policy interest rates to the effective lower bound, during and in the aftermath of the crisis, many central banks pursued further measures like targeted asset purchases and forward guidance on the policy 
rate itself, in both cases intended to reduce longer-term interest rates for private-sector borrowers and thereby stimulate nonfinancial economic activity. The analysis of monetary policy needs to be able to accommodate these monetary policy actions too. It is no longer sufficient to represent the central bank as having a single policy tool at its disposal.

The point is a fundamental one, in two ways. First, for decades the common theoretical understanding has been that monetary policy has only one independent "instrument" (in Tinbergen's (1952) vocabulary) at its disposal: it can set the quantity of its outstanding liabilities, or it can set their market price - that is, the interest rate at which they are exchanged - but it cannot independently set both. In modern times, with brief exceptions, most central banks have chosen to carry out monetary policy by setting the interest rate corresponding to banks' holdings of reserves held at the central bank. ${ }^{14}$ In their response to the 2007-9 crisis, most of the major central banks initially used the interest-rate instrument and then, once the policy interest rate had hit the lower bound, turned to the quantity instrument. Viewed from this perspective, in each phase of the response to the crisis the central bank was, as in the traditional understanding, still using only one monetary policy instrument at a time.

But the ongoing discussion of monetary policy in the post-crisis recovery has made clear that, under arrangements now in place in most of the high-income economies - specifically, with the central bank able to pay interest on banks' reserve balances - monetary policymakers need not deploy only one of these instruments at a time. The central bank's ability to choose what quantity of assets to purchase (with consequent increase in its liabilities), as many central banks did during and following the crisis, is not merely an artifact of the policy interest rate's being at the lower bound. Paying interest on reserves effectively established a floor to short-term market interest rates. Importantly, it does so without the central bank's needing to carry out 
conventional open market operations; indeed, it can even do so while the central bank is changing the quantity of its assets and liabilities in the opposite direction to what would correspond, under the traditional theory, to whatever change in the policy interest rate it is implementing at the same time. ${ }^{15}$ Given today's institutions, therefore, the central bank can choose both the quantity of its outstanding liabilities and their market price (that is, the interest rate at which they trade). Monetary policy has not one independent instrument but two.

The second way in which the monetary policy response to the $2007-9$ crisis has represented a fundamental departure is that the movement of central banks' liabilities has been, in most cases, merely the passive (and, for macroeconomic purposes, mostly irrelevant) counterpart of the changes central banks have made in their asset holdings. Policymakers' decisions, and whatever economic effects have ensued, have been a matter of the asset side of central banks' balance sheets, not their liabilities.

Numerous researchers have been actively engaged in seeking to understand, and where possible to quantify, the working of monetary policy within this new and very different theoretical framework. The necessarily simplified conceptual framework that macroeconomists teach to students of the subject - and to which they turn in their own short-hand intuitive thinking - should incorporate this changed monetary policy landscape as well. The simple model set forth here, in either its four- or five-equation form, provides a way of doing so.

\section{References}

Amano, R, and M. Shukeyev. 2012. Risk Premium Shocks and the Zero Lower Bound on Nominal Interest Rates. Journal of Money, Credit and Banking 44 (8): 1475-1505.

Bernanke, B., and A.S. Blinder. 1988. Credit, Money, and Aggregate Demand. American Economic Review 78 (2): 435-39.

Bernanke, B, and M. Gertler. 1989. Agency Costs, Net Worth, and Business Fluctuations. American Economic Review 79 (1): 14-31. 
Brayton, F., and P. Tinsley (eds.). 1996. A Guide to FRB/US - A Macroeconomic model of the United States. Washington: Board of Governors of the Federal Reserve System.

Calvo, G.A. 1983. Staggered Contracts in a Utility-Maximizing Framework. Journal of Monetary Economics 12 (3): 383-98.

Choi, W.G., and D. Cook. 2012. Fire Sales and the Financial Accelerator. Journal of Monetary Economics 59 (4): 336-51.

Christiano, L., M. Eichenbaum and C. Evans. 2005. Nominal Rigidities and the Dynamic Effects of a Shock to Monetary Policy. Journal of Political Economy 113 (1): 1-45.

Clarida, R., J. Gali and M. Gertler. 1999. The Science of Monetary Policy. Journal of Economic Literature 37 (4): 1661-1707.

Curdia, V., and M. Woodford. 2011. The Central-Bank balance Sheet as an Instrument of Monetary Policy. Journal of Monetary Economics 58 (1): 54-79.

Friedman, B.M., and K.N. Kuttner. 2011. Implementation of Monetary Policy: How Do Central Banks Set Interest Rates? In Friedman, B.M., and M. Woodford (eds.), Handbook of Monetary Economics, vol. 3B. Amsterdam: Elsevier.

Friedman, B.M., and V.V Roley. 1987. Aspects of Investor Behavior Under Risk. In Feiwel (ed.), Arrow and the Ascent of Modern Economic Theory. New York: New York University Press.

Gagnon, J.E., M. Raskin, J.A. Remache and B. Sack. 2011. The Financial market Effects of the Federal Reserve's Large-scale Asset Purchases. International Journal of Central Banking 7 (1): $3-43$.

Gertler, M., and P. Karadi. 2011. A Model of Unconventional Monetary Policy. Journal of Monetary Economics 58 (1): 17-34.

Gertler. M., and J. Leahy. 2008. A Phillips Curve with an S,s Foundation. Journal of Political Economy 116 (3): 533-72.

Gilchrist, S., and E. Zakrajsek. 2012.Credit Spreads and Business Cycle Fluctuations. American Economic Review 102 (4): 1692-1720.

Hamilton, J.D., and J.C. Wu. 2012. The Effectiveness of Alternative monetary Policy Tools in a Zero Lower Bound Environment. Journal of Money, Credit and Banking 44 (Sup.): 3-46.

Hancock, D., and W. Passmore. 2011. Did the Federal Reserve's MBS Purchase Program Lower Mortgage Rates? Journal of Monetary Economics 58 (5): 598-514. 
Holmstrom. B., and J. Tirole. 1997. Financial Intermediation, Loanable Funds, and the Real Sector. Quarterly Journal of Economics 112 (3): 663-91.

Johnson, H.G. 1971. The Keynesian Revolution and the Monetarist Counterrevolution. American Economic Review 61 (2): 1-14.

Kiyotaki, N., and J. Moore. 1997. Credit Cycles. Journal of Political Economy 105 (2): 211-48.

Krishnamurthy, A., and A. Vissing-Jorgenson. 2011. The Effects of Quantitative Easing on Interest Rates: Channels and Implications for Policy. Brookings Papers on Economic Activity $215-65$.

Roberts, J.M. 1995. New Keynesian Economics and the Phillips Curve. Journal of Money, Credit and Banking 27 (4): 975-84.

Rotemberg, J.J. 1982. Sticky Prices in the United States. Journal of Political Economy 60 (6): $1187-1211$.

Smets, F., and R. Wouters. 2003. An Estimated Dynamic Stochastic General Equilibrium Model of the Euro Area. Journal of the European Economic Association 1 (5): 1123-75.

Taylor, J.B. 1979. Staggered Contracts in a Macro Model. American Economic Review 69 (2): $108-13$.

Tinbergen, J. 1952. On the Theory of Economic Policy. Amsterdam: North-Holland.

Williams. N. 2012. Monetary Policy under Financial Uncertainty. Journal of Monetary Economics 59 (5): 449-65.

Woodford, M. 2010. Financial Intermediation and Macroeconomic Analysis. Journal of Economic Perspectives 24 (4): 21-44. 
Table 1

Central Bank Balance Sheet Expansion, 2007-2012

\begin{tabular}{lrrrr} 
Central Bank & $\begin{array}{c}\text { Balance Sheet in } \\
\text { January } 2007\end{array}$ & $\begin{array}{c}\text { Balance Sheet } \\
\text { at Maximum }\end{array}$ & $\begin{array}{c}\text { Date of } \\
\text { Maximum }\end{array}$ & Multiple \\
\hline Bank of Canada & & & & \\
European Central Bank & $€ 1,154 \mathrm{~b}$ & $€ 3,100 \mathrm{~b}$ & July 2012 & 2.7 \\
Bank of Japan & $¥ 113 \mathrm{t}$ & $¥ 158 \mathrm{t}$ & December 2012 & 1.4 \\
Riksbank & $\mathrm{kr} 199 \mathrm{~b}$ & $\mathrm{kr} 763 \mathrm{~b}$ & July 2009 & 3.8 \\
Bank of England & $£ 85 \mathrm{~b}$ & $£ 415 \mathrm{~b}$ & December 2012 & 4.9 \\
Federal Reserve System & $\$ 910 \mathrm{~b}$ & $\$ 2,979 \mathrm{~b}$ & February 2012 & 3.3 \\
& & & &
\end{tabular}




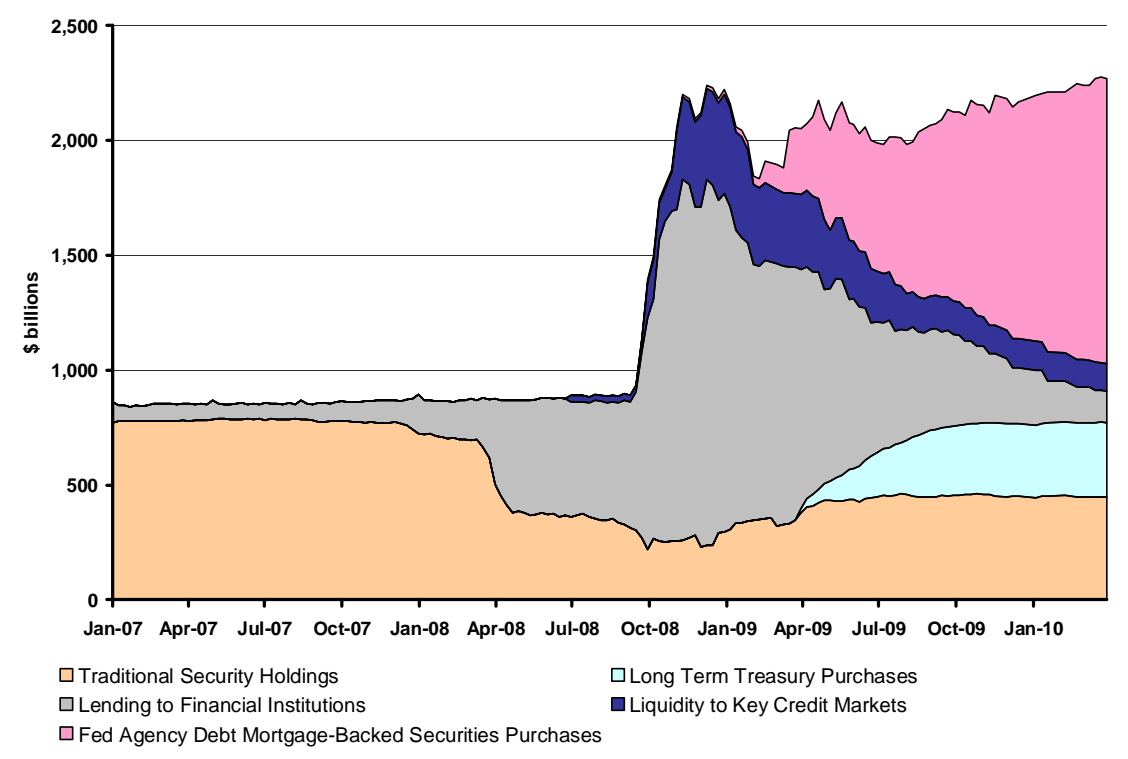

Figure 1: Federal Reserve Balance Sheet, January 2007 - March 2010

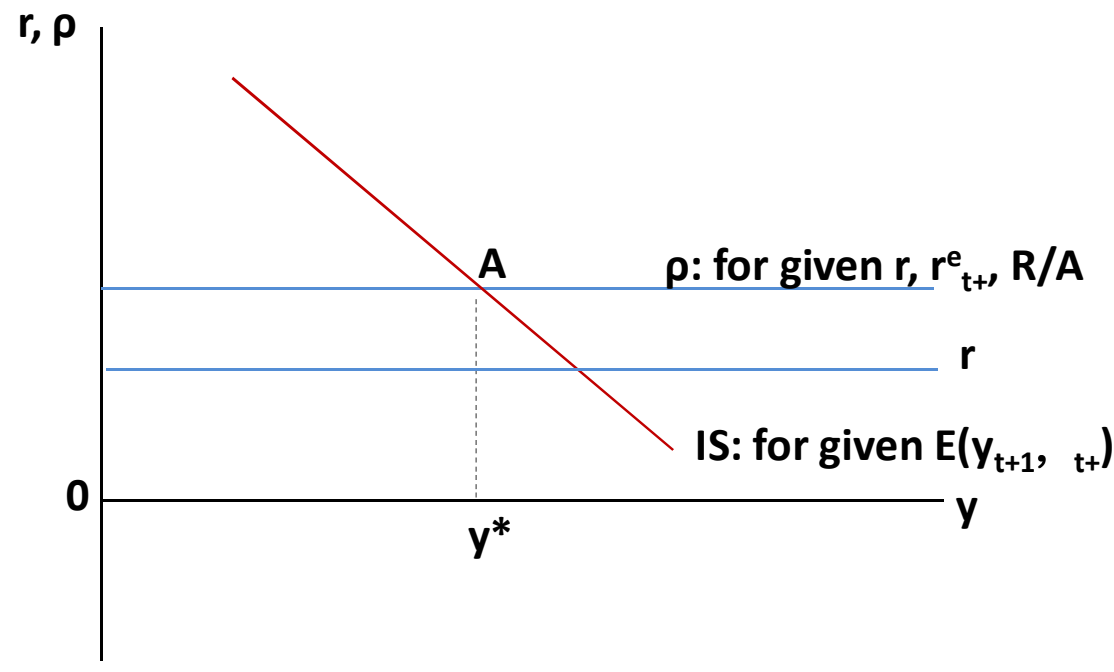

Figure 2: Determination of Income and the Private-Sector Interest Rate 


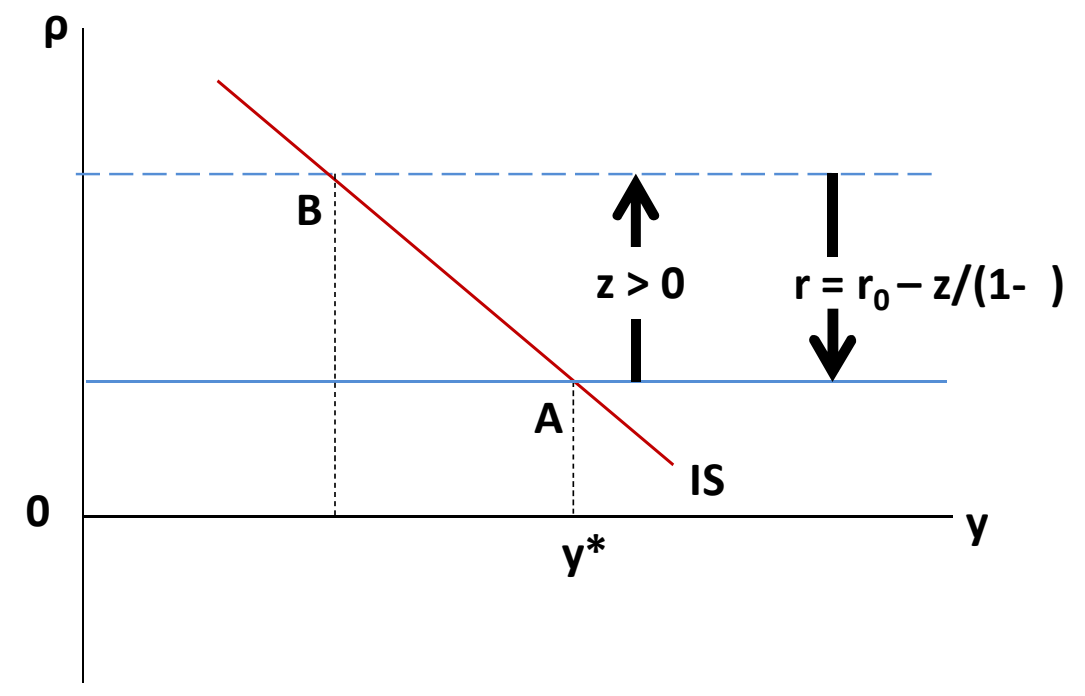

Figure 3: Effect of a Reduction in the Policy Interest Rate

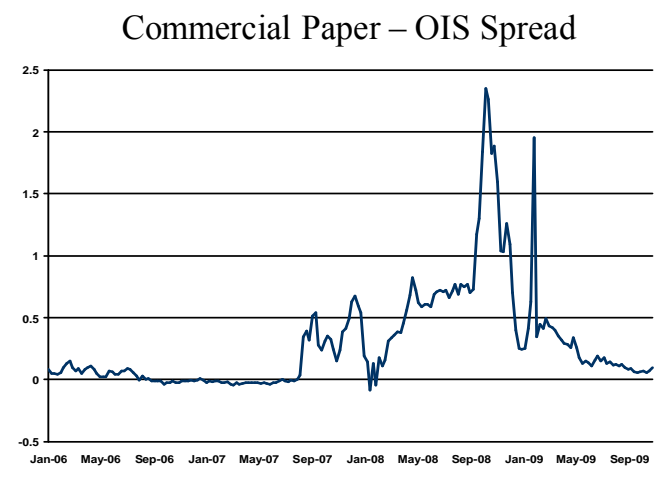

30-year Mortgage - 10-year Treasury Spread

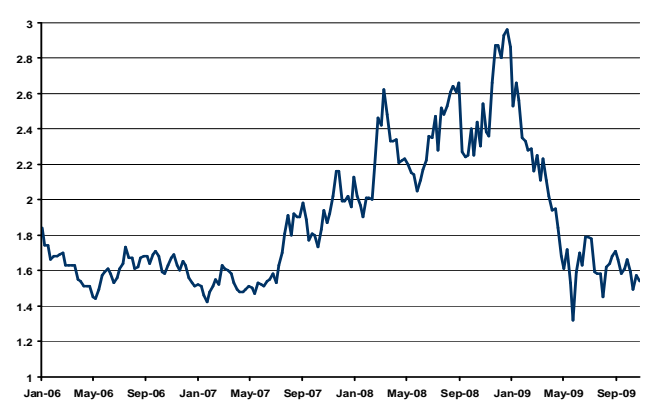

Source: Federal Reserve Board Statistical Release H.15

Figure 4: U.S. Interest Rate Spreads, January 2006 - December 2009 


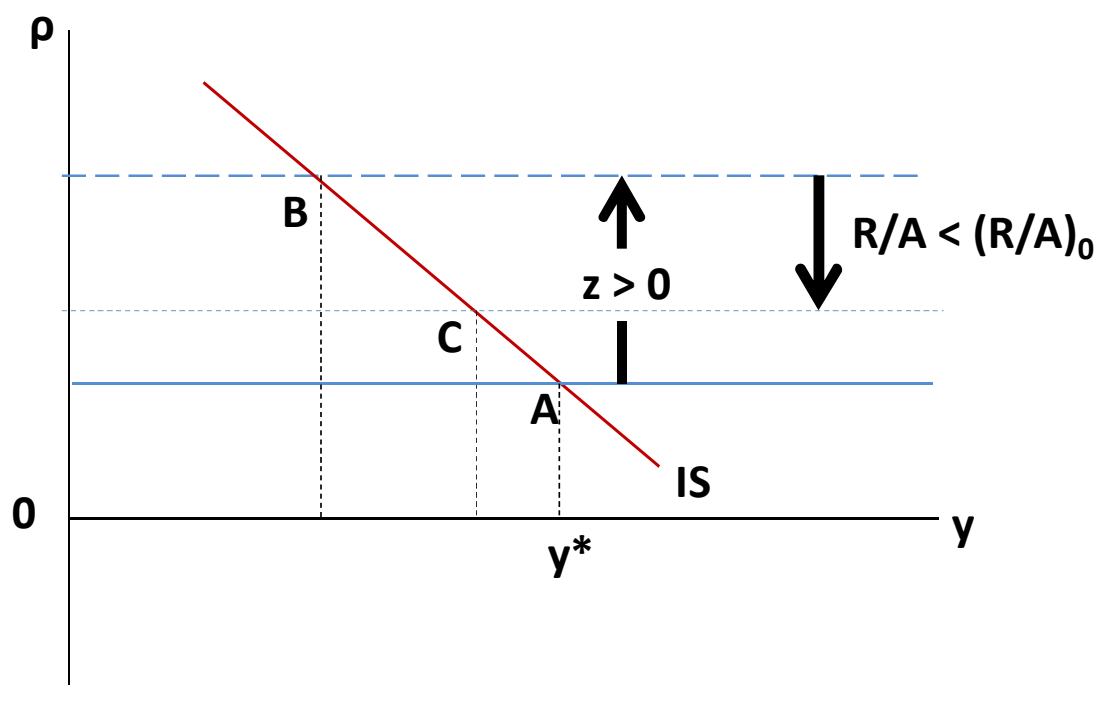

Figure 5: Effect of a Central Bank Asset Purchase

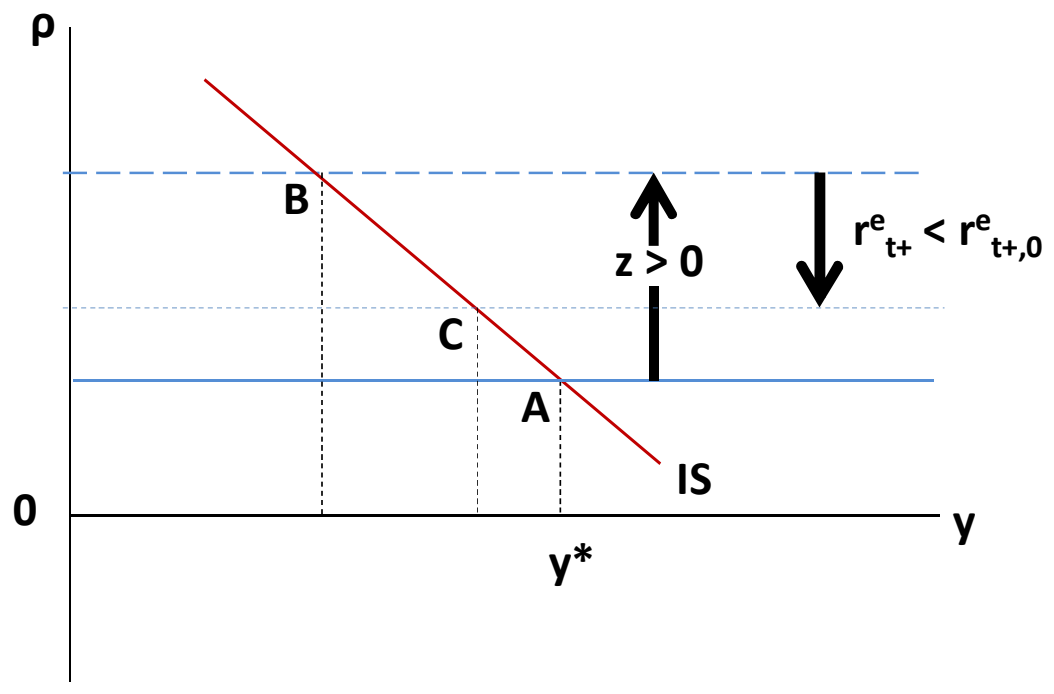

Figure 6: Effect of Forward Guidance on the Policy Interest Rate 

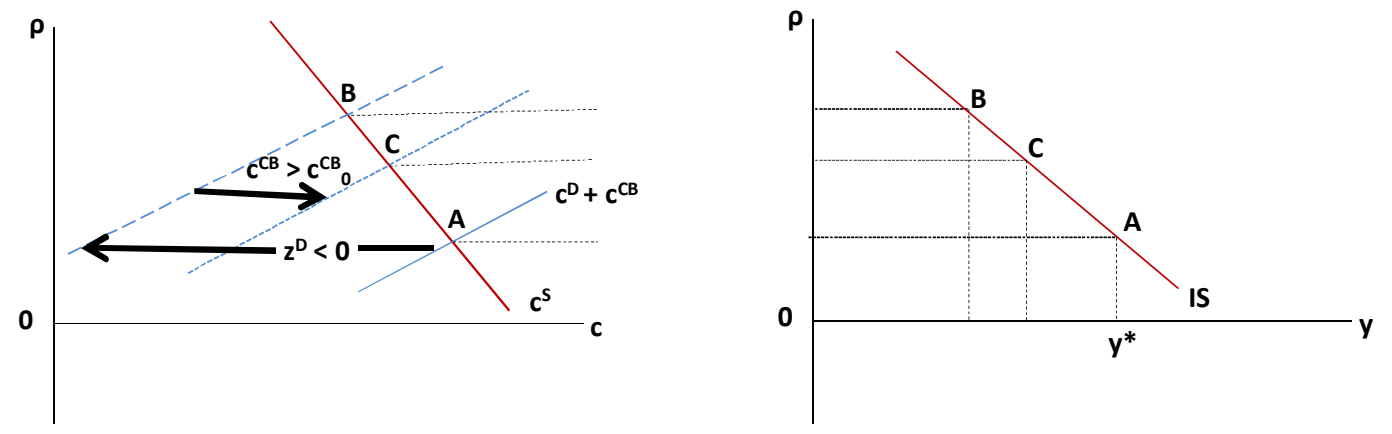

Figure 7: Effect of a Central Bank Asset Purchase (Five-Equation Model)
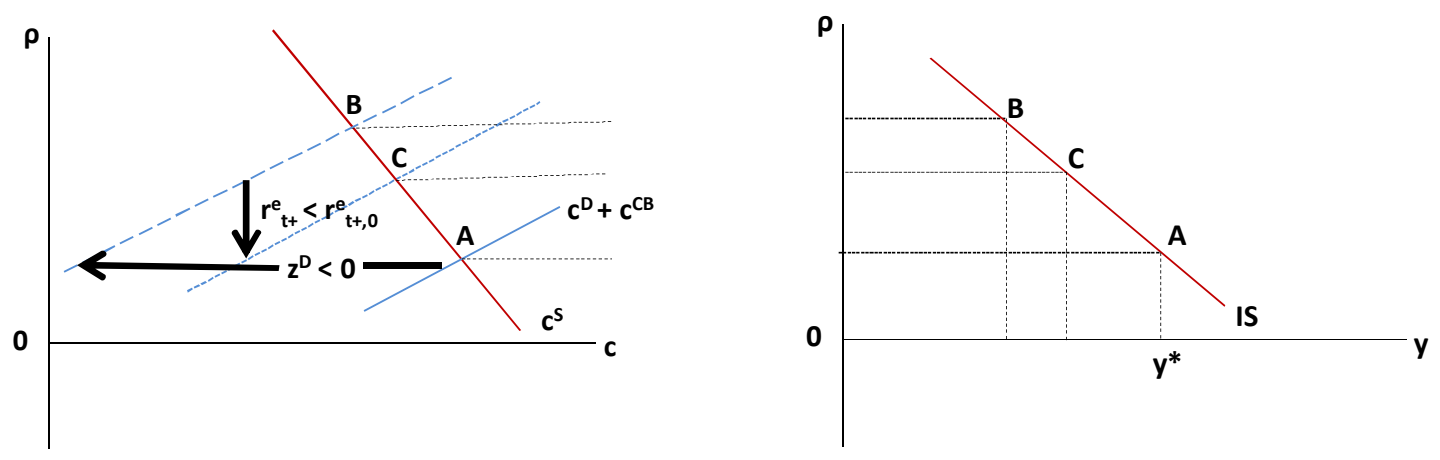

Figure 8: Effect of Forward Guidance on the Policy Interest Rate (Five-Equation Model) 


\section{Notes}

${ }^{1}$ See, for example, Brayton and Tinsley (1996), Smets and Wouters (2003) and Christiano et al. (2005).

${ }^{2}$ Bernanke and Blinder (1988), Bernanke and Gertler (1989), Holmstrom and Tirole (1997) and Kiyotaki and Moore (1997) from before the crisis, and Woodford (2010), Gertler and Karadi (2011), Gertler and Kiyotaki (2011), Curdia and Woodford (2011), Choi and Cook (2012), Gilchrist and Zakrajsek (2012), Amano and Shukayev (2012) and Williams (2012), all from after, are just a few of the most prominent examples already in the published literature as of the time of writing. The pipeline of current not-yet-published research inspired at least in part by the crisis is far larger.

${ }^{3}$ See, for example, Clarida et al. (1999). As Roberts (1995) has shown, it is not necessary to assume Calvo's specific form of price inflexibility to motivate the now-standard form of Phillips curve; staggered contracting, as in Taylor (1979), or quadratic costs of adjustment, as in Rotemberg (1982), deliver an equivalent expression for the behavior of the aggregate price level. Gertler and Leahy (2008) have shown that the familiar "S,s" model of pricing does so as well.

${ }^{4}$ See Friedman and Kuttner (2011) on what enables the central bank to do this.

${ }^{5}$ The introduction of private-sector borrowing and lending (beyond the mere existence of a market in which no one chooses to participate) also means that the model can no longer bear the interpretation of a representative agent: if all private agents were identical, there would be no reason for any one of them to borrow from or lend to any other. But for purposes here, there is no need for a representative-agent model.

${ }^{6}$ An alternative way to represent this kind of forward guidance would be to posit that the central bank has adopted a new behavioral pattern to replace its historical behavior as in (2), and the purpose of the public announcement is to inform investors about this change.

${ }^{7}$ When investors have constant relative risk aversion, and believe that returns on risky assets are normally distributed, asset demands are linear in expected excess returns so that this relationship is linear as well; see Friedman and Roley (1987).

${ }^{8}$ Shocks to the credit market like a decline in borrowers' collateral value or an erosion of lenders' capital may also result in increased credit rationing - that is, borrowers' inability to obtain loans despite willingness to pay the interest rate charged to similar borrowers who do receive loans. The model presented here abstracts from such rationing, and therefore implicitly treats the spread $(\rho-r)$ as a sufficient statistic for this influence on aggregate demand as well.

${ }^{9}$ See, for example, Gagnon et al. (2011), Hancock and Passmore (2011), Krishnamurthy and Vissing-Jorgenson (2011) and Hamilton and $\mathrm{Wu}$ (2012). 
${ }^{10}$ Here it is even more apparent that with private-sector borrowing and lending what results cannot be a representative-agent model.

${ }^{11}$ The linearity with respect to expected excess returns again follows under conditions of constant relative risk aversion and normally distributed returns; substitutability coefficient $\theta_{2}$ in $\left(4^{\mathrm{D}}\right)$ is then directly proportional to investors' total wealth (A in the corresponding reduced-form expression in the four-equation model), and inversely proportional to the coefficient of relative risk aversion and to the variance associated with the risky asset's return. See again Friedman and Roley (1987).

${ }^{12}$ For given initial quantities of private-sector obligations outstanding, and a given amount held by the central bank, $c^{\mathrm{S}}, \mathrm{c}^{\mathrm{D}}$ and $\mathrm{c}^{\mathrm{CB}}$ can be equivalently interpreted as either flows or stocks. The market-clearing condition $\left(4^{\mathrm{MC}}\right)$ makes clear that the model developed here abstracts from credit rationing; see again fn. 8 .

${ }^{13}$ It is also possible to suggest ways in which a reduced value of borrowers' collateral would depress $\mathrm{c}^{\mathrm{S}}$ - that is, would reduce the demand to borrow even if there were no change in lenders' willingness to lend to them at a given interest rate. But the effect on $\mathrm{c}^{\mathrm{D}}$ is more straightforward, and it is what the literature analyzing the 2007-9 crisis has mostly emphasized.

${ }^{14}$ One prominent exception before the 2007-9 crisis was the U.S. Federal Reserve's experiment with a nonborrowed reserves operating procedure during 1979-82.

${ }^{15}$ See Friedman and Kuttner (2011) for a detailed discussion of this feature of monetary policy implementation. 